\title{
Longitudinal changes in the abundance of filter feeders and zooplankton in lake-outlet streams in northern Sweden
}

\author{
Å.I. Eriksson ${ }^{1}$
}

Keywords : filter feeders, zooplankton, longitudinal distribution, lake-outlet streams.

The Sheldon \& Oswood (1977) model, that predicts a linear relationship between log filter-feeder density and log distance from a lake and assumes proportionality between filter-feeder density and seston concentration, was tested on data from four lake-outlet streams. In addition, longitudinal changes in species composition and body size in zooplankton were investigated. Most filter feeders deviated from the model and a quadratic, rather than linear, decrease in density was a common pattern. Total filter feeders and blackfly larvae showed a hump-shaped distribution pattern. Lower current velocity at sites close to lakes is suggested as an explanation. No general proportional relationship between net-spinning caddis larvae and zooplankton was found and several reasons for this result are discussed. Zooplankton biomass and mean zooplankton body length decreased with distance from lakes. The abundance of cyclopoid adults, copepodites, and nauplii declined at a higher rate than Bosmina spp: This result indicates that factors such as selective predation by filter-feeders and/or taxon-specific sedimentation rates, are acting to reduce zooplankton abundance in these lake-outlet streams.

Variations longitudinales dans l'abondance des organismes filtreurs et du zooplancton dans les déversoirs de lac du nord de la Suède

Mots-clés : organismes filtreurs, zooplancton, distribution longitudinale, réservoirs de lac.

Le modèle de Sheldon \& Oswood (1977) qui prédit une relation linéaire entre le log de la densité des organismes .et le log de la distance du lac et qui se manifeste par une proportionnalité entre la densité des organismes filtreurs et la concentration du seston, a été contrôlé sur des données recueillies sur quatre cours d'eau déversoirs de lac. De plus, les variations longitudinales dans la composition des espèces et la taille du corps du zooplancton ont été examinées. La plupart des organismes filtreurs relevait de ce modèle et une diminution de la densité plutôt quadratique que linéaire a constitué le modèle-type. Le total des organismes filtreurs et de larves de simulies a montré une figure de distribution en forme de courbe sinusoïdale. Ce résultat pourrait être dû à une vitesse de courant plus faible près des lacs. Aucune relation proportionnelle générale entre les larves de trichoptères tisseurs de toile et le zooplancton n'a été décelée et plusieurs raisons explicatives ont été envisagées. La biomasse des espèces zooplanctoniques et la longueur moyenne de leur corps décroit en fonction de leur éloignement aux lacs. L'abondance des cyclopoïdes adultes, copépodites et nauplii diminue plus que celle des espèces de Bosmina. Ces résultats montrent que les facteurs tels que la prédation sélective des organismes filtreurs et/ou les taux de sédimentation spécifique des taxons jouent un rôle dans la réduction de l'abondance du zooplancton dans les déversoirs lacustres. 


\section{Introduction}

Dense assemblages of filter-feeding invertebrates are often found at lake outlets (Richardson \& Mackay 1991). Longitudinal studies of lake-outlet streams have shown that filter-feeder density and/or biomass decline rapidly with distance from the lake (Illies 1956, Brönmark \& Malmqvist 1984, Robinson \& Minshall 1990). There is no doubt that the high production of filter feeders in lake outlets is related to the high concentrations of nutrient-rich particles in the lake water (Wallace \& Merritt 1980, R.C. Petersen 1987) and the downstream decline in filter-feeder density is often explained by a downstream change in seston composition caused by filter feeding and/or sedimentation (Richardson \& Mackay 1991). Whilst the total seston concentration may not decrease with distance from the lake (Cushing 1963, Oswood 1979, Valett \& Stanford 1987, Morin \& Peters 1988), there is strong evidence for a downstream decrease in seston quality, measured as amount of zooplankton, protein, ATP and, in some cases, phytoplankton or chlorophyll $a$ in the water (Chandler 1937, Maciolek \& Tunzi 1968, Valett \& Stanford 1977, Parker \& Voshell 1983, Brönmark \& Malmqvist 1984).

Sheldon \& Oswood (1977) developed a simple model to predict the decline in filter-feeder density and seston concentration with increasing distance from a lake based on two assumptions : 1) filter-feeder density is proportional to seston concentration at any point along the outlet stream and 2) seston removal is caused mainly by filter-feeder consumption. This model predicts a linear decline in the logarithm of filter-feeder density and the logarithm of seston concentration with the logarithm of distance from lake, resulting in a slope of -1 . The model has been tested for filter feeders and phytoplankton in single streams in a number of studies, and filter feeders generally provide a good fit to the model (Sheldon \& Oswood 1977, Oswood 1979, Brönmark \& Malmqvist 1984). However, no studies have reported proportionality between filter-feeder density and phytoplankton concentration. Instead, a faster decline in filter-feeder density than in phytoplankton concentration seems to be a common pattern in single streams (Carlsson et al. 1977, Sheldon \& Oswood 1977, Oswood 1979, Brönmark \& Malmqvist 1984). Despite the fact that phytoplankton (e. g. diatoms) is an important food resource for filter feeders (Maciolek \& Tunzi 1968, Fuller \& Mackay 1981), there is no strong evidence of phytoplankton being a limiting resource for either blackflies, or net-spinning caddis larvae in lake-outlet streams.
Zooplankton is of higher nutritional quality than phytoplankton for net-spinning caddis larvae in lakeoutlet streams (Benke \& Wallace 1980, Parker \& Voshell 1983, Fuller et al. 1988), and relationships between the amount of animal material in the water and density/biomass of filtering caddisflies have been found (Richardson 1984, R.C. Petersen 1987). L.B.-M. Petersen (1987) showed that hydropsychids actively prefer zooplankton when offered different natural food particles. The density of zooplankton declines rapidly with distance from a lake (Chandler 1937, Voshell \& Parker 1985). A longitudinal change in zooplankton species composition, from larger to smaller, more compact-bodied, species has also been reported (Sandlund 1982, Herlong \& Mallin 1985). To my knowledge, the predictions of the model of Sheldon \& Oswood (1977) has never been tested for zooplankton.

In this paper, I report the results of a study of riffle filter-feeders in four lake-outlet streams in northern Sweden. The objectives were to (i) test the generality of Sheldon \& Oswood's model for different filter-feeding taxa, (ii) examine the first assumption of the model, with regards to density of net-spinning caddis larvae and zooplankton concentration, and (iii) investigate the generality of longitudinal changes in zooplankton community structure and zooplankton body size.

\section{Study streams}

The lake-outlet streams are located in the province of Västerbotten in northern Sweden, within $120 \mathrm{~km} \mathrm{~W}$ of Umeå. Environmental data concerning the lakes, obtained from 1 : 50000 topographic maps, are summarised in Table 1. Being situated in the boreal zone, the lakes are oligotrophic, although Djupsjön and Hjoggsjön are influenced by agriculture, and the lakes are normally ice covered from the beginning of December until mid May. The bedrock in the area is dominated by hard-weathered silicate minerals and the calcium content is low. There are no man-made dams at the outlets and although rapids are separated by sections of slowly nunning water, all streams lack pools in the investigated reaches. The stream discharge in this geographical area generally peaks in late May or early June, due to snow melt, decreases during the summer, and reaches minimum values in January-April (Giller \& Malmqvist 1998). In a longitudinal study, where distance from lake is an important factor, it may sometimes be difficult to identify the exact point of origin of the stream as the transformation is a gradual process. In Djupsjöbäcken, Hjoggsjöbäcken and Kullabäcken the starting points were set where the lakes suddenly turn into narrow; slow-flowing streams. Ekorrbäcken 
Table 1. Environmental data, physical and chemical characteristics of the water (mean values from all sites in each stream $\pm \mathrm{SD}$ ), and sampling site distances from lakes, for the different lake-outlet streams.

Tableau 1. Données environnementales, caractéristiques physiques et chimiques de l'eau (valeurs moyennes de toutes les stations dans chaque cours d'eau \pm SD) et distances entre les lacs et les stations de prélèvements, pour les différents déversoirs lacustres.

\begin{tabular}{|c|c|c|c|c|}
\hline & Ekorrbäcken & Djupsjöbäcken & Hjoggsjöbäcken & Kullabäcken \\
\hline Geographic position & $\begin{array}{l}64^{\circ} 30 \mathrm{~N} \\
19^{\circ} 05^{\prime} \mathrm{E}\end{array}$ & $\begin{array}{l}63^{\circ} 45 \mathrm{~N}, \\
19^{\circ} 30^{\prime} \mathrm{E}\end{array}$ & $\begin{array}{l}63 \cdot 55 \mathrm{~N} \\
19^{\circ} 45^{\prime} \mathrm{E}\end{array}$ & $\begin{array}{l}63.49 \mathrm{~N} \\
20^{\circ} 19 \mathrm{E}\end{array}$ \\
\hline Altitude (m) & 209.6 & 98.0 & 139.9 & 68.8 \\
\hline Land use in surroundings & Forest & Agriculture & Agriculture & Forest \\
\hline Lake area $\left(\mathrm{km}^{2}\right)$ & 3.648 & 0.408 & 1.136 & 0.100 \\
\hline Conductivity $(\mu \mathrm{S} / \mathrm{cm})$ & $23.6( \pm 1.1)$ & $31.8( \pm 1.6)$ & $27.6( \pm 0.7)$ & $35.5( \pm 1.36)$ \\
\hline Temperature $\left({ }^{\circ} \mathrm{C}\right)$ & $11.6( \pm 0.5)$ & $13.8( \pm 0.1)$ & $13.1( \pm 1.0)$ & $14.1( \pm 1.9)$ \\
\hline $\mathrm{pH}$ & $6.05( \pm 0.05)$ & $6.08( \pm 0.11)$ & $6.05( \pm 0.06)$ & $5.99( \pm 0.08)$ \\
\hline Width (m) & $10.0( \pm 4.0)$ & $2.5( \pm 0.5)$ & $2.8( \pm 0.8)$ & $4.2( \pm 1.6)$ \\
\hline Depth (m) & $0.42( \pm 0.12)$ & $0.18( \pm 0.03)$ & $0.27( \pm 0.12)$ & $0.33( \pm 0.15)$ \\
\hline Current velocity $(\mathrm{cm} / \mathrm{s})$ & $58( \pm 21)$ & $51( \pm 7)$ & $63( \pm 15)$ & $53( \pm 18)$ \\
\hline $\begin{array}{l}\text { Benthic sampling sites (m } \\
\text { from lake) }\end{array}$ & $\begin{array}{l}1,20,125,250 \\
9000\end{array}$ & $\begin{array}{l}150,350,640 \\
1100\end{array}$ & $10,40,140,600$ & $\begin{array}{l}30,45,120 \\
4500\end{array}$ \\
\hline $\begin{array}{l}\text { Zooplankton/abiotic } \\
\text { sampling sites (m from lake) }\end{array}$ & $1,125,9000$ & $20,350,1100$ & $10,140,600$ & $1,120,4500$ \\
\hline
\end{tabular}

drains a narrow part of the lake where a natural threshold marks the beginning of the stream. The predominant substrate particle size categories (based on the Wentworth Scale, Giller \& Malmqvist 1998) in all streams were small and large cobbles, although boulders were common close to the lake in Hjoggsjöbäcken.

\section{Methods}

Sampling was performed between June 9 and June 14,1994 . The location of the different study sites in relation to the lakes is shown in Table 1. Stream width, water depth and current velocity were measured at the benthic sampling sites. Current velocity was measured in the midwater at three points on a transect across the stream at each site, using an Ott current velocity meter. All benthic samples were taken in riffles. A Surbersampler with a mesh-size of $0.25 \mathrm{~mm}$ and a sampling area of $0.929 \mathrm{~m}^{2}$ was used and the substrate was disturbed by hand to a depth of approximately $10 \mathrm{~cm}$.
Samples were preserved in $70 \%$ ethanol. The most upstream site was always located in the first riffle downstream of the lake where dense aggregations of Neureclipsis bimaculata (L.) catch-nets started to appear. Hence, sampling sites were situated at different distances in the different streams (in one case as far as $150 \mathrm{~m}$ from the lake). Distances between sites gradually increased downstream and the most downstream site in each stream was defined as the upstream part of the first riffle appearing at a distance of $>500 \mathrm{~m}$ from the lake. In Kullabäcken and Ekorrbäcken, extended reaches of slowly running water caused the most downstream sites to be situated at much longer distances from the lakes than in the other streams. Three to four benthic samples were taken systematically from a transect across the stream at each site. Edge zones were avoided to reduce boundary effects. Sorting and identification of invertebrates were done in the laboratory.

Four zooplankton samples per site were taken at three sites in each stream, and the first site was at the 
outlet (Table 1). At the same sites, conductivity, temperature and $\mathrm{pH}$ were measured twice. Each zooplankton sample consisted of $50 \mathrm{~L}$ of water, sieved through a $60 \mu \mathrm{m}$ mesh plankton net. Samples were collected by submerging and filling a $10 \mathrm{~L}$ bucket five times. By using this method (given the moderate water depths, Table 1), the whole water column including the water surface should be sampled. Samples were preserved in $70 \%$ ethanol. Identification of zooplankton and body length measurements were performed in the laboratory. Copepods were identified to order and cladocerans to the genus level.

Prior to statistical analyses, distance data were standardised by subtracting the distance from the lake to the first sampling point from the actual distance from the lake at each site. Hence, the most upstream sites were given a distance of $0 \mathrm{~m}$. This procedure was motivated by ecological similarities (based on species composition and current velocity) at these sites among streams. Data on filter-feeder density, zooplankton biomass, and distance from lake were $\log _{10}(1+x)$ transformed in all analyses whereas zooplankton body-length data were $\log _{10}(x)$-transformed. General longitudinal distributions of filter-feeding invertebrates and zooplankton biomass were analysed using ANCOVAs with mean density (or biomass in the case of zooplankton) from each site as the dependent variable, stream as a fixed factor, and distance and the square of distance as covariates. In cases where the effect of the square of distance was not significant, this term was removed and the analysis was repeated with distance as the only covariate. The reason for analysing filter-feeder density, rather than biomass, was simply that density is included in Sheldon \& Oswood's model, whereas no predictions concerning filter-feeder biomass is made. All statistical tests were performed in SPSS 7.0.

\section{Results}

Mean values of conductivity, temperature, $\mathrm{pH}$-values, stream width, water depth and current velocity are presented in Table 1 . Conductivity was generally low, ranging from $23.2 \mu \mathrm{S} \mathrm{cm}^{-1}$ in Ekorrbäcken to 37.5 $\mu \mathrm{S} \mathrm{cm}-1$ in Kullabäcken. Temperature ranged from $11.1^{\circ} \mathrm{C}$ in Ekorrbäcken to $15.6^{\circ} \mathrm{C}$ in Kullabäcken. $\mathrm{pH}$ values were close to 6 in all streams. Ekorrbäcken was wider and deeper than the other streams. Current velocity was lowest at the most upstream sites in all streams, with values between 28 and $40 \mathrm{~cm} \mathrm{~s}^{-1}$. At the other sites, current velocity ranged from 54 to $70 \mathrm{~cm} \mathrm{~s}^{-1}$.
The analyses of general longitudinal patterns in different filter-feeding taxa (Table 2, Fig. 1) showed that the square of distance contributed significantly to the models in many cases, the exceptions being Neureclipsis bimaculata, Pisidium spp. and filtering chironomids. In total filter feeders and blackflies, both covariates were significant, reflecting a general hump-shaped distribution pattern (Fig. 1A, B). Blackflies dominated the filter-feeder community by number and, hence, had a strong impact on the pattern found in total filter feeders. The abundance of net-spinning caddis larvae showed a general quadratic decline with distance (Fig. 1C), and the significant interaction terms (streamxdistance and/or streamxthe square of distance) in net-spinning caddis larvae and Hydropsyche siltalai Döhler, showed that the effect of the covariates varied between streams (Table 2). The distribution pattern of $H$. siltalai was hump-shaped in two streams, monotonically decreasing with distance in one stream, and was U-shaped in one stream (Fig. 1D). Significant differences in density among streams were found in Polycentropus flavomaculatus (Pictet) only (Fig. 1F, Table 2). N. bimaculata and Pisidium spp. declined linearly with distance, with slopes $( \pm 95 \%$ C. I.) of $-0.78( \pm 0.50)$ and $-0.48( \pm 0.37)$, respectively, whereas no significant longitudinal pattern was found in filtering chironomids (Fig 1E, G, H, Table 2). There was a tendency towards a U-shaped pattern, though, and filtering chironomids were negatively correlated with blackflies $(\mathrm{r}=-0.48, \mathrm{p}=0.05)$. Pisidium spp. and filter-feeding chironomids contributed little to total filter-feeder density $(0.3 \%$ and $1.2 \%$ of total number of filter feeders, respectively).

An ANCOVA model including distance and the square of distance did not provide a satisfactory fit to the data on log zooplankton biomass (Table 3, Fig. 2). Instead, untransformed zooplankton biomass decreased linearly with distance, and there were significant differences among streams in slopes (streamxdistance) and in the levels of zooplankton biomass (Table 3). There was no significant correlation between zooplankton biomass and density of net-spinning caddis larvae (Pearson's correlation, $r=0: 44, p=0.17$, $\mathrm{n}=11$ ), based on mean values from the sites where both variables were measured.

Cyclopoid copepods, cyclopoid nauplii and Bosmina spp. dominated the zooplankton community in all streams. The concentrations of different zooplankton taxa at the most upstream sites are shown in Figure 3. Daphnia spp. occurred in low numbers and only close to lakes. Paired t-tests on the proportions (arcsine square root transformed data) of each taxon remaining 
Table 2. ANCOVA models providing significant descriptions of changes in mean values of lot filter-feeder densities $\left(\right.$ no. $\left./ \mathrm{m}^{2}\right)$ from each site with $\log$ distance from lakes $(\mathrm{m})$. n.s. denotes p-values $>0.05$.

Tableau 2. Modèles ANCOVA fournissant les meilleures descriptions des changements du log des densités des organismes filtreurs $\left(\right.$ no. $/ \mathrm{m}^{2}$ ) avec le log de distances entre les lacs et les stations de prélèvements $(\mathrm{m}) \mathrm{ns}$ dénote des valeurs $\mathrm{p}>0.05$.

\begin{tabular}{|c|c|c|c|c|c|}
\hline Dependent variable & Source of variation & d.f. & MS & $\mathbf{F}$ & p.... \\
\hline \multirow[t]{6}{*}{ Filter feeders } & Stream & 3 & 0.179 & 0.940 & n.s. \\
\hline & Distance & 1 & 2.066 & 10.823 & 0.022 \\
\hline & Distance $^{2}$ & 1 & 2.751 & 14.409 & 0.013 \\
\hline & Stream×Distance & 3 & 0.634 & 3.320 & n.s. \\
\hline & Stream $\times$ Distance ${ }^{2}$ & 3 & 0.728 & 3.813 & n.s. \\
\hline & Error & 5 & 0.191 & & \\
\hline \multirow[t]{6}{*}{ Blackflies } & Stream & 3 & 0.689 & 1.284 & n.s. \\
\hline & Distance & 1 & 3.870 & 7.212 & 0.044 \\
\hline & Distance $^{2}$ & 1 & 4.501 & 8.389 & 0.034 \\
\hline & Stream $\times$ Distance & 3 & 0.603 & 1.124 & n.s. \\
\hline & Stream $\times$ Distance ${ }^{2}$ & 3 & 0.984 & 1.834 & n.s. \\
\hline & Error & 5 & 0.537 & & \\
\hline \multirow[t]{6}{*}{ Net-spinning caddis larvae } & Stream & 3 & 0.411 & 2.852 & n.s. \\
\hline & Distance & 1 & 0.374 & 2.598 & n.s. \\
\hline & Distance $^{2}$ & 1 & 1.615 & 11.209 & 0.020 \\
\hline & Stream $\times$ Distance & 3 & 0.798 & 5.539 & 0.048 \\
\hline & Stream $\times$ Distance $^{2}$ & 3 & 0.695 & 4.823 & n.s. \\
\hline & Error & 5 & 0.144 & & \\
\hline \multirow[t]{6}{*}{ H. siltalai } & Stream & 3 & 0.302 & 3.116 & n.s. \\
\hline & Distance & 1 & 1.094 & 11.288 & 0.020 \\
\hline & Distance $^{2}$ & 1 . & 1.950 & 20.118 & 0.006 \\
\hline & Stream $\times$ Distance & 3 & 0.813 & 8.385 & 0.021 \\
\hline & Stream $\times$ Distance ${ }^{2}$ & 3 & 0.825 & 8.507 & 0.021 \\
\hline & Error & 5 & 0.097 & & \\
\hline \multirow[t]{4}{*}{ N. bimaculata } & Stream & 3 & 0.363 & 1.046 & n.s. \\
\hline & Distance & 1 & 13.513 & 38.976 & 0.000 \\
\hline & Stream $\times$ Distance & 3 & 0.301 & 0.867 & n.s. \\
\hline & Error & 9 & 0.347 & & \\
\hline \multirow[t]{6}{*}{ P. flavomaculatus } & Stream & 3 & 1.287 & 13.478 & 0.008 \\
\hline & Distance & 1 & 0.422 & 4.418 & n.s. \\
\hline & Distance $^{2}$ & 1 & 1.093 & 11.445 & 0.020 \\
\hline & Stream $\times$ Distance & 3 & 0.217 & 2.277 & n.s. \\
\hline & Stream $\times$ Distance ${ }^{2}$ & 3 & 0.096 & 1.006 & n.s. \\
\hline & Error & 5 & 0.096 & & \\
\hline \multirow[t]{4}{*}{ Pisidium spp. } & Stream & 3 & 0.104 & 0.569 & n.s. \\
\hline & Distance & 1 & 6.937 & 37.791 & 0.000 \\
\hline & Stream $\times$ Distance & 3 & 0.049 & 0.268 & n.s \\
\hline & Error & 9 & 0.184 & & \\
\hline \multirow[t]{4}{*}{ Filtering chironomids } & Stream & 3 & 0.040 & 0.070 & n.s. \\
\hline & Distance & 1 & 0.002 & 0.003 & n.s. \\
\hline & Stream $\times$ Distance & 3 & 0.322 & 0.565 & n.s. \\
\hline & Error & 9 & 0.569 & & \\
\hline
\end{tabular}



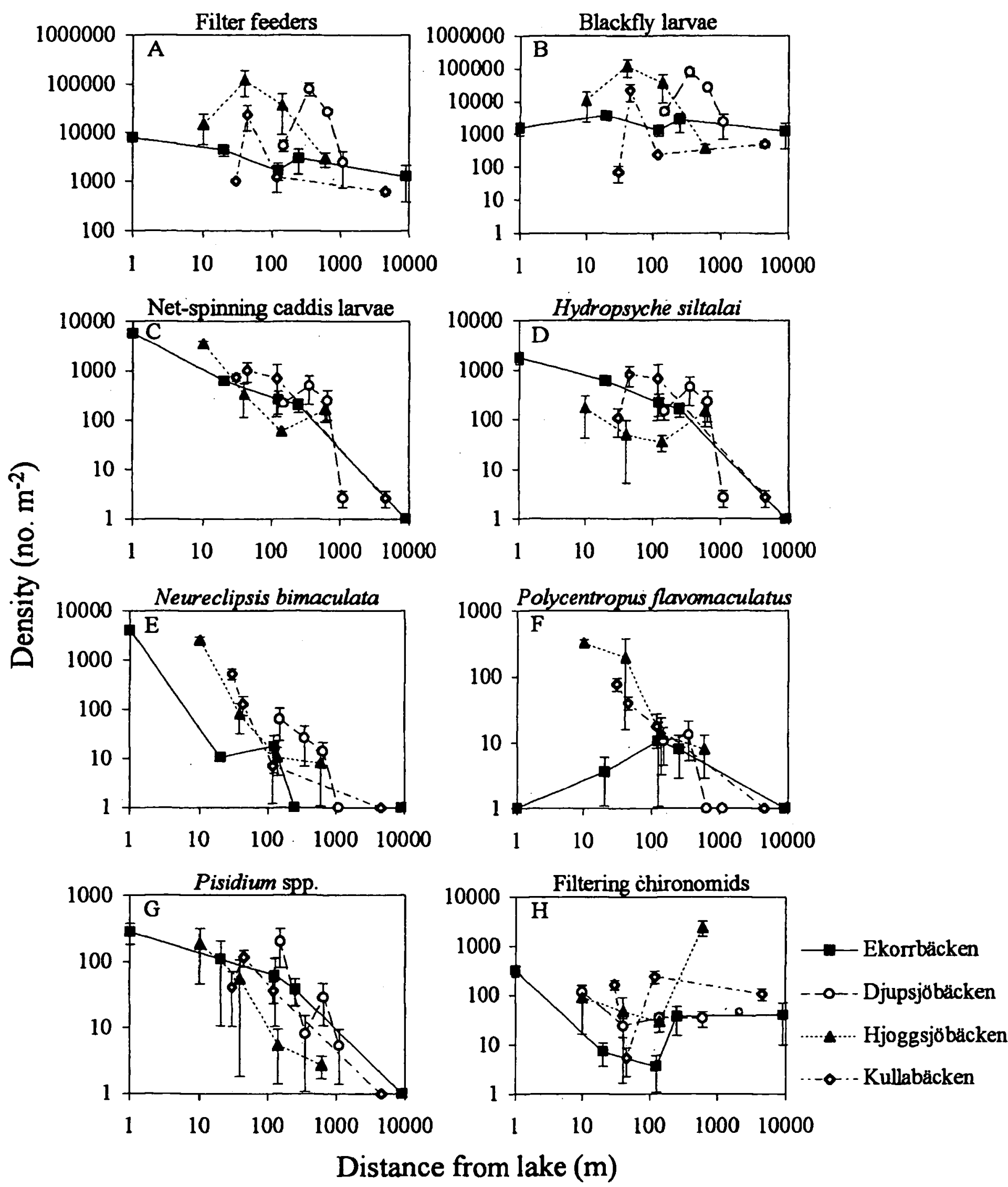

Fig. 1. Longitudinal changes in densities of different filter-feeding taxe. A) total filter feeders, B) blackfly larvae, C) total netspinning caddis larvae, D) Hydropsyche siltalai, E) Neureclipsis bimaculata, F) Polycentropus flavomaculatus, G) the bivalve Pisidium spp., H) filtering chironomids. Mean values \pm SE. Note the differences in scales on the $y$-axes.

Fig. 1. Variations longitudinales de la densité des organismes filtreurs. A) nombre total d'organismes filtreurs, B) larves de Simulies, C) nombre total de larves de trichoptères tisseurs de toile, D) Hydropsyche siltalai, E) Neureclipsis bimaculata, F) Polycentropus flavomaculatus, G) famille des Pisidium bivalves, H) Chironomidés filtreurs. Valeurs moyennes \pm SD. 
Table 3. ANCOVA models from the analyses on changes in zooplankton biomass $(\mu \mathrm{g} / \mathrm{L})$ with log distance from lakes $(\mathrm{m})$. n.s. denotes p-values $>0.05$.

Tableau 3. Tableaux ANCOVA des analyses de changements dans la biomasse de zooplancton $(\mu \mathrm{g} / \mathrm{L})$ avec le log de distances entre les lacs et les stations de prélèvements $(\mathrm{m})$. ns dénote des valeurs $\mathrm{p}>0.05$.

\begin{tabular}{|c|c|c|c|c|c|}
\hline Dependent variable & Source of variation & d.f.f. & MS & $\mathbf{F}$ & p... \\
\hline \multirow[t]{4}{*}{ Log zooplankton biomass } & Stream & 3 & 0.243 & 0.482 & n.s. \\
\hline & Distance & 1 & 0.191 & 0.380 & n.s. \\
\hline & Distance $^{2}$ & 1 & 0.020 & 0.039 & n.s. \\
\hline & Error & 6 & 0.504 & & \\
\hline \multirow[t]{4}{*}{ Zooplankton biomass } & Stream & 3 & 1.277 & 18.742 & 0.008 \\
\hline & Distance & 1 & 8.971 & 131.691 & 0.000 \\
\hline & Stream $\times$ Distance & 3 & 0.835 & 12.255 & 0.017 \\
\hline & Error & 4 & 0.068 & & \\
\hline
\end{tabular}

in the water at the second and third sampling sites (Fig. 4), revealed that the reduction in Bosmina spp. was significantly lower than the reduction in cyclopoid adults/copepodites $(\mathrm{t}=3.58, \mathrm{p}<0.05)$, and nauplii $(\mathrm{t}=3.20, \mathrm{p}<0.05)$, whereas no significant differences were found between cyclopoid adults/copepodites and nauplii $(t=0.89, \mathrm{p}<0.05)$. Since the risk of committing Type 1 errors increases when multiple comparisons are performed, the significance level, $\alpha$, was set to 0.01 in the paired t-tests, which gives a true $\alpha$ of 0.03 (Zar 1996). The average body length of zooplankton decreased linearly with distance from lakes (Fig. $5),\left(R^{2}=0.47, p<0.05\right.$, d.f. $\left.=11\right)$. A similar pattern was found for Bosmina spp. (Fig. 5), $\left(\mathrm{R}^{2}=0.52\right.$, $\mathrm{p}<0.05$, d.f. $=10$ ). Analyses on body-size reduction in copepods and cyclopoid nauplii could not be performed because of low numbers (or absence) at sites far from lakes. At the most upstream sites, mean body length ( $\pm 95 \%$ C. I.) was $0.64 \pm 0.15 \mathrm{~mm}$ for cyclopoid copepods, $0.20 \pm 0.03 \mathrm{~mm}$ for cyclopoid nauplii and $0.32 \pm 0.05 \mathrm{~mm}$ for Bosmina spp.

\section{Discussion}

The model of Sheldon \& Oswood (1977) is, at present, the only available model that could be used to predict longitudinal changes in filter-feeder density and seston concentration in lake-outlet streams. A major advantage of the model is that it is easily tested for any filter-feeding species in any lake-outlet stream. However, the results from this study revealed that the density of filter feeders does not always decline linearly with distance from lake, as predicted by the model, and that the distribution patterns may differ between taxa, and within taxa among streams. A significant pat- tern was a gradual build-up in filter-feeder density, especially pronounced in blackfly larvae, within the first 20-350 m downstream of the lakes, followed by a decline. A similar pattern has been reported in previous studies (Brönmark \& Malmqvist 1984, Robinson \& Minshall 1990). An underlying mechanism could be that, in the absence of dams, current velocity tends to be lower close to lakes, leading to a lower rate of food supply, and many filter-feeders may be more likely to respond to food supply per unit time (delivery rate) than to seston concentration per se (Robinson \& Minshall 1990). This hypothesis could, however, not be applied to active filter feeders, such as Pisidium spp.,

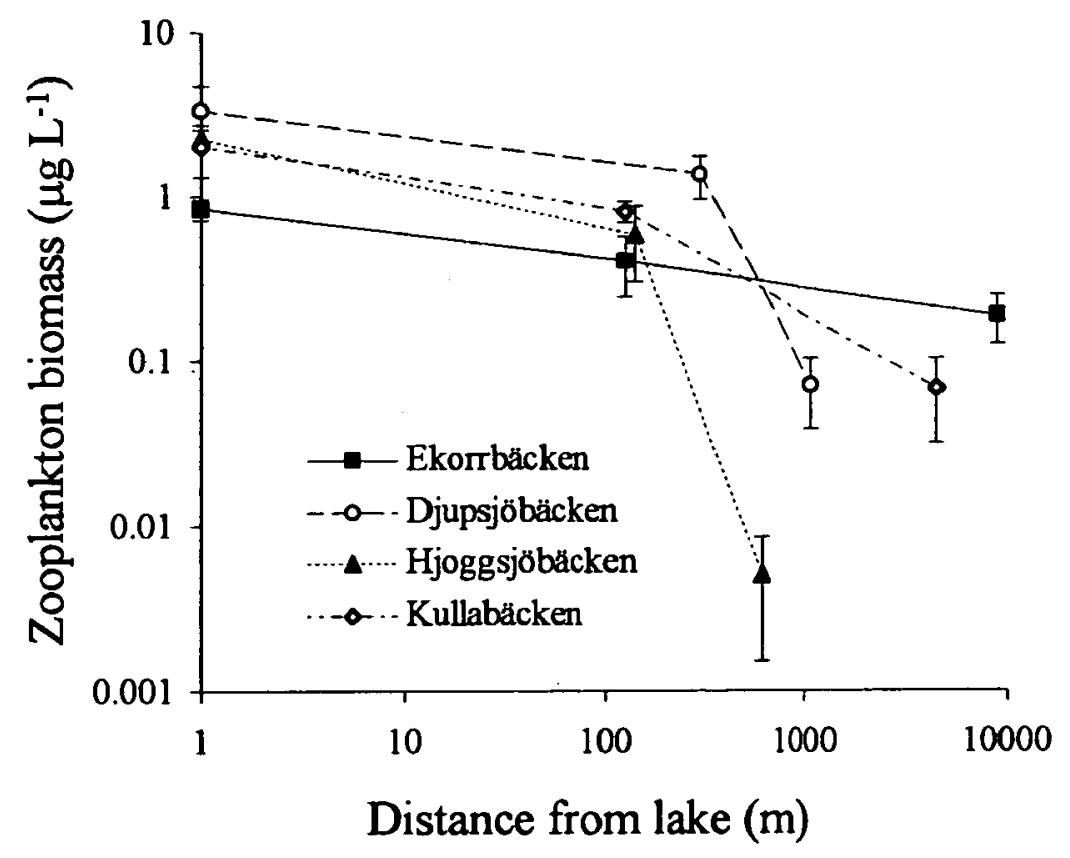

Fig. 2. Longitudinal changes in zooplankton biomass. Mean values $\pm \mathrm{SD}$.

Fig. 2. Variations longitudinales de la biomass du zooplancton. Valeurs moyennes $\pm \mathrm{SD}$. 


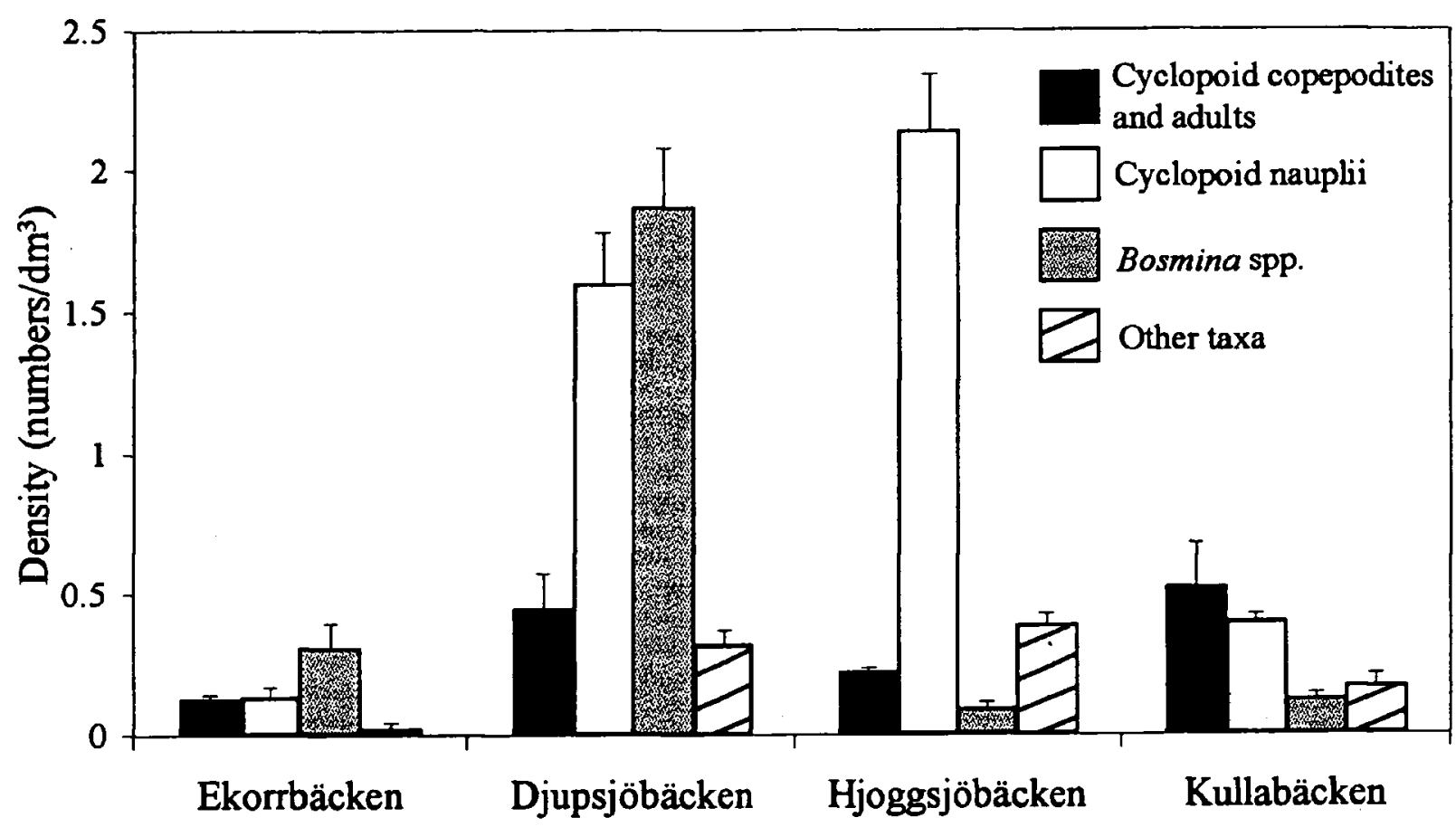

Fig. 3. Density of different zooplankton taxa at the most upstream sites. Mean values $\pm S E$.

Fig. 3. Abondances des différents taxa zooplanctoniques dans les stations situées à l'amont. Valeurs moyennes $\pm \mathrm{SD}$.

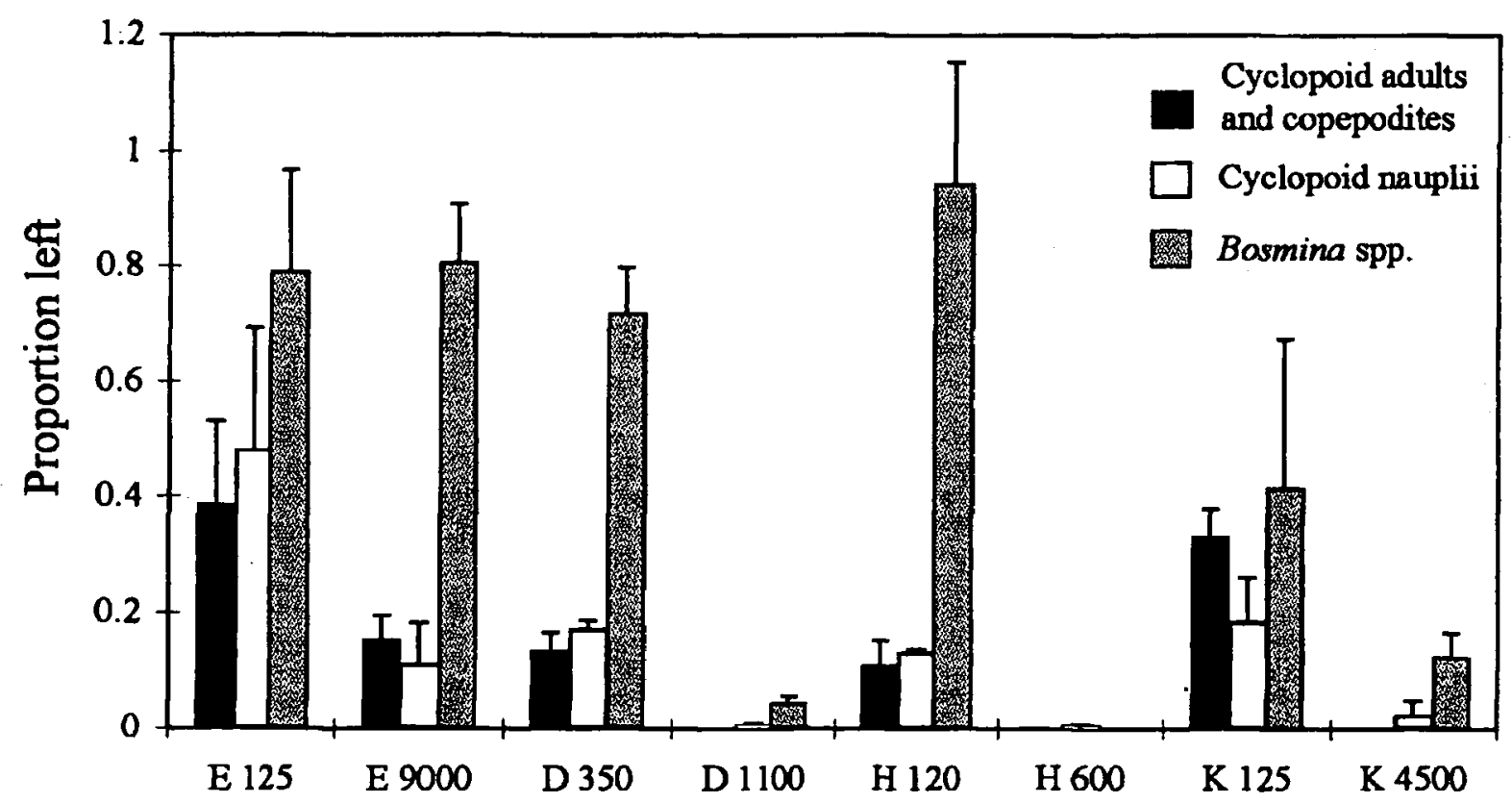

Fig. 4. Mean proportions (the concentration of a taxon at a specific site divided by the average concentration of that taxon at the most upstream site) \pm SE of different zooplankton taxa remaining in the water at different distances from the lakes. Proportions at the first sampling sites are not shown, since they, by definition, were 1 . $E=$ Ekorrbäcken, $D=$ Djupsjöbäcken, $H=$ Hjoggsjöbäcken, $K=$ Kullabäcken. Numbers denote distance from the lake $(m)$.

Fig. 4. Proportions moyennes (la concentration d'un taxon à une station donnée divisée par la concentration moyenne de ce taxon dans la station la plus en amont) \pm SE de différents taxa zooplanctoniques restant dans l'eau à des distances différentes des lacs. Les proportions aux premières stations de prélèvement ne sont pas indiquées, puisque par définition, elles étaient $1 . \mathrm{E}=$ Ekorrbäcken, $\mathrm{D}=$ Djupsjöbäcken, $\mathbf{H}=$ Hjoggsjöbäcken, $K=$ Kullabäcken. Les chiffres indiquent les distances du lac (m). 
since their food intake should be independent of the ambient current velocity, and Pisidum spp. also declined linearly with distance. In this study, current velocity varied between 28 and $70 \mathrm{~cm} / \mathrm{s}$ and the lowest values were measured at the most upstream sites. These sites were included to give estimates of the densities of Neureclipsis bimaculata, a typical lake-outlet species whose delicate catch-nets are unable to withstand higher current velocities (Edington 1968). To my knowledge, longitudinal studies on seston delivery rate on a larger scale have not been performed. On a smaller scale, though, Englund (1991) noticed that a reduced delivery rate, caused mainly by a decline in current velocity, resulted in decreases in growth rate and establishment in Hydropsyche siltalai larvae. If filter feeders respond to seston delivery rate rather than to seston concentration, the assumption of proportionality between filter-feeder density and seston concentration would be seriously violated whenever delivery rate is not proportional to concentration at all sites, e. g. in streams with a longitudinal gradient in current velocity. This could explain the fact that no evidence of proportionality between density of net-spinning caddis larvae and zooplankton biomass was found. The delivery rate experienced by the filter feeders is the product of food particle concentration and the current velocity through the filtering devices. Thus, when testing the delivery rate hypothesis, the depth at which current velocity is measured may be crucial, since there are often weak (or no) correlations between current velocities at different depths (Hart et al. 1996). Unfortunately, in this study, both zooplankton and current velocity data were too coarse to allow a test of the delivery rate hypothesis.

However, failures to show proportionality between filter feeders and their food resources (Carlsson et al. 1977, Sheldon \& Oswood 1977, Oswood 1979, Brönmark \& Malmqvist 1984) do not necessarily imply that the assumptions of the model are false, since longitudinal patterns in both filter-feeder density and seston are likely to be highly dynamic on a temporal scale. For example, lake-outlet insect species grow and emerge at different times of the year (Carlsson et al. 1977, Lake \& Burger 1983, Mackay \& Waters 1986) and filter-feeder density and feeding rate may vary with season (Maciolek \& Tunzi 1968, Sheldon \& Oswood 1977). The seasonal changes in benthic community structure are slow, though, compared to the quantitative and qualitative changes in important food resources, like phytoplankton and zooplankton (Sommer 1989). Vadeboncoeur (1994) found that longitudinal changes in seston quality (bacteria and chlorophyll a) were related to stream discharge. Under periods of low discharge, the reduction in seston quality was more pronounced than under high discharge conditions. It is reasonable to assume that the reduction in zooplankton biomass is also a function of stream discharge, since a higher proportion of the water passes through the bottom substratum and through the filtering devices of filter feeders at low discharge. Therefore, expecting proportional relationships between seston concentration and filter-feeder density at any time of the year in all lake-outlet streams is probably unrealistic. A prerequisite for finding relationships between an organism and its food resource is, of course, knowledge concerning what food resource is the most limiting for that organism. For instance, a non-linear relationship between net-spinning caddis larvae and zooplankton biomass could be expected if other food resources were more important to net-spinning caddis larvae than zooplankton. This hypothesis, however, is strongly contradicted by previous studies (Benke \& Wallace 1980, Richardson 1984, Valett \& Stanford 1987, Fuller et al. 1988), although Fuller \& Mackay (1981) showed that the relative importance of different food particles may vary with season.

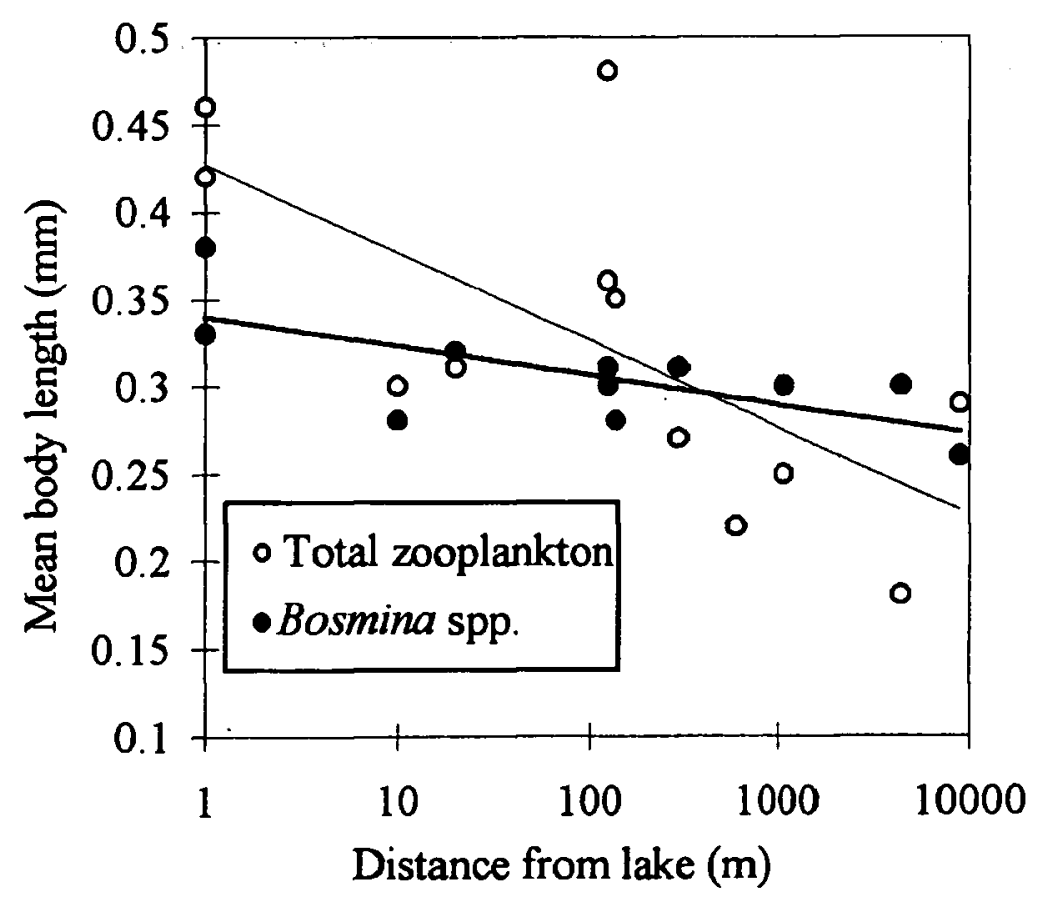

Fig. 5. Longitudinal changes in zooplankton body length. Points are mean values from each site in all streams. Bold line $=$ Bosmina spp, thin line $=$ total zooplankton.

Fig. 5. Variations longitudinales de la taille du zooplancton. Les points représentent les valeurs moyenṇes à chaque station pour les quatre réservoirs. Ligne grasse : Bosmina spp ; ligne fine = zooplancton total. 
The distribution of filter feeders is, of course, not only affected by food supply. For instance, although providing a good fit to the model, N. bimaculata was probably more limited by the downstream increases in current velocity (Edington 1968), than by decreases in food-particle concentration. Further, biotic interactions, e. g. competition for space and/or predation, could influence the distribution of filter feeders (Brönmark \& Malmqvist 1984, Hemphill 1988, Malmqvist et al. 1991), although Morin (1991) regarded microhabitat features as being more important structuring forces than biotic interactions. Both biotic interactions and abiotic conditions probably contributed to the high variability in density within and between sites in this study. Without detailed investigations, however, it is difficult to separate these two factors. For example, the negative correlation between filtering chironomids and blackfly larvae might indicate competition between the two taxa, but could also be a result of differences in microhabitat preferences. Also, the two polycentropodids in the study, N. bimaculata and P. flavomaculatus, showed different longitudinal distribution patterns without being negatively correlated to each other. Both are low current species, but may have different substratum requirements, since the nets of $N$. bimaculata are often placed on top of stones or attached to vegetation (personal observation), whereas $P$. flavomaculatus build their nets under stones (Edington 1968). Still, despite a high variability, a decline in filter-feeder density with distance from a lake on a larger scale, seems to be a consistent and general pattern which is hard to explain without considering longitudinal differences in food supply (Illies 1956, Maciolek \& Tunzi 1968, Sheldon \& Oswood 1977, Valett \& Stanford 1977, Oswood 1979, Parker \& Voshell 1983, Brönmark \& Malmqvist 1984, Robinson \& Minshall 1990).

Interestingly, there were differences in the rate of decline among zooplankton taxa with distance, and despite differences in relative abundance among streams, the same pattern was found in all streams. The largest zooplankton taxon, cyclopoid copepods, showed the highest reduction rates in all streams. Faster downstream reductions in large-bodied zooplankton taxa than in smaller, more compact-bodied species, have been reported previously (Sandlund 1982, Herlong \& Mallin 1985), and Herlong \& Mallin (1985) interpreted this pattern as a higher ability of smaller zooplankters to withstand sedimentation, the forces of turbulent water, and size-selective predation by invertebrates or fish. The reduced size of Bosmina spp. with increasing distance from a lake indicates that such mechanisms are acting on zooplankton in this study. However, des- pite a smaller body size, cyclopoid nauplii generally showed a steeper decline than Bosmina spp. It is possible that the spiny appearance of cyclopoid nauplii makes them more «sticky» than the more compact-bodied Bosmina, and hence more easily caught by filterfeeders. These should be primarily caddis larvae, but the average size of the nauplii was well inside the food-particle size range of blackfly larvae (Wotton 1982), and since blackfly larvae are non-selective filter feeders (Carlsson et al. 1977, Wotton 1978), it is possible that the reduction in cyclopoid nauplii was influenced by predation from both caddis larvae and blackfly larvae. However, the impact of abiotic factors, such as strong hydraulic forces and sedimentation, on taxon-specific reduction rates in zooplankton has, to my knowledge, never been tested experimentally and may provide an alternative explanation to the patterns found in this study.

It is important to bear in mind that the results from this study only reflect the situation at the date of sampling. Sampling was performed in the beginning of June, prior to the flight period of most filtering insect species and shortly after peak discharge, and, given the temporal aspects mentioned above, repeated sampling later in the summer would probably have yielded different results in terms of density and species composition of both filter feeders and zooplankton. For a full understanding of, on the one hand, the limiting ability of nutrient-rich seston on filter-feeder distribution and, on the other hand, the role of filter feeders in the processing of lake-derived food particles, it is probably necessary to combine long-term field studies with mechanistic investigations of the feeding behaviour of filter feeders.

\section{Acknowledgements}

I thank Prof. Björn Malmqvist, Dr. Göran Englund, and two anonymous reviewers for constructive comments on previous versions of the manuscript. Dr. P. Grampeix kindly prepared the French abstract. I also thank Stefan Henriksson and Dan Evander for valuable help with sorting and identification. This study was supported by Helge Ax : son Johnsons Stiftelse.

\section{References}

Benke A.C. \& Wallace J.B. 1980. - Trophic basis of production among net-spinning caddisflies in a southern Appalachian stream. Ecology, 61 : 108-118.

Brönmark C. \& Malmqvist B. 1984. - Spatial and temporal patterns of lake outlet benthos. Verh. Internat. Verein. Limnol., 22 : 1986-1991.

Carlsson M., Nilsson L.M., Svensson Bj., Ulfstrand S. \& Wotton R. S. 1977. - Lacustrine seston and other factors influencing the blackflies (Diptera : Simuliidae) inhabiting lake outlets in Swedish Lapland. Oikos, 29 : 229-238.

Chandler D.C. 1937. - Fate of typical lake plankton in streams. Ecol. Monogr., 7 : 445-479. 
Cushing C.E. Jr. 1963. - Filter-feeding insect distribution and planktonic food in the Montreal river. Trans. Am. Fish. Soc., 92 : 216-219.

Edington J.M. 1968. - Habitat preferences in net-spinning caddis larvae with special reference to the influence of water velocity. $J$. Anim. Ecol., 37 : 675-692.

Englund G. 1991. - Asymmetric resource competition in a filterfeeding stream insect (Hydropsyche siltalai ; Trichoptera). Freshwat. Biol., $26: 425-432$.

Fuller R.L. \& Mackay R.J. 1981. - Effects of food quality on the growth of three Hydropsyche species (Trichoptera : Hydropsychidae). Can. J. Zool., 59: 1133-1140.

Fuller R.L., Fry T.J. \& Roelofs J.A. 1988. - Influence of different food types on the growth of Simulium vittatum (Diptera) and $H y$ dropsyche betteni (Trichoptera). J. N. Am. Benthol. Soc., 7 (3) : 197-204.

Giller P.S. \& Malmqvist B. 1998. - The Biology of Streams and Rivers. Oxford University Press, Oxford : 296 p.

Hart D.D., Clark B.D. \& Jasentuliyana A. 1996. - Fine-scaled measurement of benthic flow environments inhabited by stream invertebrates. Limnol. Oceanogr., 41 : 297-308.

Hemphill N. 1988. - Competition between two stream-dwelling filter-feeders, Hydropsyche oslari and Simulium virgatum. Oecologia, 77 : 73-80.

Herlong D.D. \& Mallin M.A. 1985. - The benthos-plankton relationship upstream and downstream of a blackwater impoundment. J. Freshwat. Ecol., $3: 47-59$.

Illies J. 1956. - Seeausfluss-Biozönosen lappländicher Waldbäche. Entomol. Tidskr., 77 : 138-153.

Lake D.J. \& Burger J.F. 1983. - Larval distribution and succession of outlet-breeding blackflies (Diptera : Simuliidae) in New Hampshire. Can. J. Zool., $61: 2519-2533$.

Maciolek J.A. \& Tunzi M.G. 1968. - Microseston dynamics in a simple Sierra Nevada lake-stream system. Ecology, $49: 60-75$.

Mackay R.J. \& Waters T.F. 1986. — Effects of small impoundments on hydropsychid caddisfly production in Valley Creek, Minnesota. Ecology, $67: 1680-1686$.

Malmqvist B., Rundle S., Brönmark C. \& Erlandsson A. 1991. Invertebrate colonization of a new man-made stream in southern Sweden. Freshwat. Biol., $26:$ 307-324.

Morin A. \& Peters R.H. 1988. - Effect of microhabitat features, seston quality, and periphyton on the abundance of overwintering black fly larvae in southern Québec. Limnol. Oceanogr., 33 : 431-446.

Morin A. 1991. - Intensity and importance of abiotic control and inferred competition on biomass distribution patterns of Simuliidae and Hydropsychidae in southern Québec streams. J. N. Am. Benthol. Soc., $10: 388-403$.
Oswood M.W. 1979. - Abundance patterns of filter-feeding caddisflies (Trichoptera : Hydropsychidae) and seston in a Montana (U.S.A.) lake outlet. Hydrobiologia, 63 : 177-183.

Parker C.R. \& Voshell J.R. Jr. 1983. - Production of filter-feeding Trichoptera in an impounded and a free-flowing river. Can. J. Zool., $61:$ 70-87.

Petersen L.B.-M. 1987. - Field and laboratory studies of the biology of three species of Hydropsyche (Trichoptera : Hydropsychidae). $\mathrm{PhD}$ thesis, University of Lund, Sweden : $142 \mathrm{p}$.

Petersen R.C. Jr. 1987. - Seston quality as a factor influencing trichopteran populations. In : Bournaud M. \& Tachet H. (eds.), Proc. 5th Int. Symp. Trichoptera. Dr W. Junk Publishers : 287-292.

Richardson J.S. 1984. - Effects of seston quality on the growth of a lake-outlet filter feeder. Oikos, $43: 386-390$.

Richardson J.S. \& Mackay R.J. 1991. — Lake outlets and the distribution of filter feeders : an assessment of hypotheses. Oikos, 62 : 370-380.

Robinson C.T. \& Minshall G.W. 1990. — Longitudinal development of macroinvertebrate communities below oligotrophic lake outlets. Great Basin Nat., $50: 303-311$.

Sandlund O.T. 1982. - The drift of zooplankton and microbenthos in the river Strandaelva, western Norway. Hydrobiologia, 94 : 33-48.

Sheldon A.L. \& Oswood M.W. 1977. — Blackfly (Diptera : Simuliidae) abundance in a lake outlet : test of a predictive model. $\mathrm{Hy}$ drobiologia, $56: 113-120$.

Sommer U. 1989. - Plankton Ecology. Springer-Verlag. Berlin, Heidelberg, New York: 369 p.

Vadeboncoeur Y. 1994. - Longitudinal dynamics of seston concentration and composition in a lake outlet stream. J. N. Am. Benthol. Soc., 13 : 181-198.

Valett H.M. \& Stanford J.A. 1987. — Food quality and hydropsychid caddisfly density in a lake outlet stream in Glacier National Park, Montana, USA. Can. J. Fish. Aquat. Sci., 44 : 77-82.

Voshell J.R. \& Parker C.R. 1985. - Quantity and quality of seston in an impounded and a free-flowing river in Virginia, U.S.A. $H y$ drobiologia, $122: 271-280$.

Wallace J.B. \& Merritt R.W. 1980. - Filter-feeding ecology of aquatic insects. Ann. Rev. Entomol., $25: 103-132$.

Wotton R.S. 1978. - The feeding rate of Metacnephia tredecimatum larvae (Diptera : Simuliidae) in a Swedish lake outlet. Oïkos, $30: 121-125$.

Wotton R.S. 1982. - Does the surface film of lakes provide a source of food for animals living in lake outlets ? Limnol. Oceanogr., 27 : 959-960.

Zar J.H. 1996. - Biostatistical Analysis $3^{\text {rd }}$ ed. Prentice-Hall. Upper Saddle River, New Jersey. 662 p. 